\title{
$\nabla$
}

\section{The importance of the dermatologist at the hospital *} A importância do dermatologista no ambiente hospitalar

\author{
Luciana Cirillo Maluf Azevedo ${ }^{1}$ \\ Maura Simonetti Junqueira de Andrade ${ }^{3}$ \\ Mellysande Pontes Faccin (In memorian)
}

\author{
Carlos D' Aparecida Santos Machado Filho ${ }^{2}$ \\ Alessandra Bunemer Nahas ${ }^{4}$
}

\begin{abstract}
Skin lesions are often underestimated when patients are hospitalized in clinical or surgical areas. We made weekly visits to Mario Covas State Hospital of Sao Paulo, Brazil, for 35 weeks. Patients answered a questionnaire and underwent skin examination. The skin lesions were photographed. Of the 359 patients evaluated, a total of 1098 dermatological conditions were diagnosed. The most prevalent skin conditions included photodermatosis, neoplasms, vasculopathies and onychopathies. The growing number of dermatological diseases in hospitals justifies the active and constant presence of the dermatologist in a multidisciplinary team, thereby improving prognosis and patients' quality of life. Keywords: Hospitalization; Morbidity; Neoplasms; Prevalence; Skin diseases; Skin neoplasms

Resumo: As lesões dermatológicas costumam ser subestimadas quando da internação do paciente nas áreas clínica ou cirúrgica. Foram feitas visitas aos leitos do Hospital Estadual Mário Covas, do Estado de São Paulo - Brasil, durante 35 semanas. Os pacientes responderam um questionário e foram submetidos ao exame clínico dermatológico. As lesões cutâneas foram fotografadas. Nos 359 pacientes avaliados, foram encontrados 1098 diagnósticos dermatológicos. Os grupos mais prevalentes foram fotodermatoses, neoplasias, onicopatias e vasculopatias. O crescente número de afecções dermatológicas no ambiente hospitalar justificaria a presença mais ativa e constante do dermatologista na equipe multidisciplinar, melhorando o prognóstico e a qualidade de vida do doente.

Palavras-chave: Dermatopatias; Hospitalização; Morbidade; Neoplasias; Neoplasias cutâneas; Prevalência
\end{abstract}

Skin abnormalities are common, affecting one quarter to one third of the general population at some point in life; however, little is known about the prevalence and type of dermatologic disease affecting patients in hospitals. ${ }^{1}$

Although dermatology is predominantly an outpatient specialty, some patients require hospitalization. ${ }^{2}$ The number of hospital admissions primarily due to skin infection or systemic diseases with skin manifestations, diagnosed by doctors or nondermatol- ogists is growing; consequently, dermatological interconsultations are increasing. ${ }^{2}$

Non-dermatology specialists have failed to properly diagnose some important skin diseases during hospitalization. If skin diseases are to be taken more seriously, a better approach should be established regarding disease progression and treatment, with a more active presence of the dermatologist in the hospital. ${ }^{1}$

We made weekly visits to Mario Covas State

Received on 10.08.2011

Approved by the Advisory Board and accepted for publication on 22.11.2012.

* Work conducted at Mario Covas State Hospital - ABC School of Medicine (HEMC-FMABC) - Santo André (SP), Brazil.

Conflict of interest: None

Financial funding: None

Dermatologist, assistant at the Dermatology Service of Faculdade de Medicina do ABC (ABC School of Medicine) - FMABC - Santo André (SP), Brazil. Professor of Dermatology, ABC School of Medicine (FMABC) - Santo André (SP), Brazil.

Resident, Internal Medicine, ABC School of Medicine (FMABC) - Santo André (SP), Brazil.

Student of Medicine, ABC School of Medicine (FMABC) - Santo André (SP), Brazil.

PhD, Urgent Care Medicine, Universidade Federal de São Paulo (Federal University of Sao Paulo) - (UNIFESP) - Professor of Propedeutics, ABC School of Medicine (FMABC) - Head of the Internal Medicine Ward, Hospital Estadual Mário Covas (Mario Covas State Hospital)- ABC School of Medicine (HEMCFMABC) - Santo André (SP), Brazil. 
Hospital for 35 weeks and described skin lesions to report the prevalence of dermatological diseases.

Of the 528 patients evaluated, 359 were included in the study, from clinical and surgical wards and intensive care units. We assessed gender, race, age, underlying disease responsible for admission, and food and drug allergies. A clinical dermatologic examination was conducted. The examination involved the scalp, glabrous skin, mucous membranes, nails, lymph nodes, and peripheral nerves. Skin lesions were photographed.

The study was submitted to the Ethics Committee of Mario Covas State Hospital and the Ethics Committee of $\mathrm{ABC}$ School of Medicine for approval. Both institutions approved the study protocol.

We grouped the skin diseases into categories as shown in table 1. Skin disorders caused or influenced by sunlight - with inflammatory or degenerative alteration - were considered photodermatoses. ${ }^{3}$ We diagnosed 1098 skin lesions, with an average of three dermatoses for each patient visited.

The average patient age was 55.2. A total of 196 (55\%) were men and 163 (45\%) were women. Most were white $(75 \%)$, followed by pardos (grayish-brown, 13\%) and black (11\%); hospitalization averaged 10.2 days.

Among photodermatoses, solar melanoses and leukoderma were more frequent; rhomboidal skin, poikiloderma of Civatte, and a case of porphyria cutanea tarda were also found.

Direct mycological examinations were not conducted in the group of onychopathies.

Pressure ulcers, bedsores, bruises, ecchymoses and petechiae, purpura and Raynaud's phenomenon

TABLE 1: Distribution of all dermatoses in the areas evaluated at Mario Covas State Hospital, Santo Andre - Sao Paulo, 2009

\begin{tabular}{ll}
\hline Distribution of all dermatoses & N (\%) \\
\hline Photodermatoses & $226(20.58)$ \\
Neoplasms & $222(20.21)$ \\
Onychopathies & $177(16.12)$ \\
Vasculopathies & $95(8.65)$ \\
Eczematous Dermatoses & $87(7.92)$ \\
Infectious Dermatoses & $72(6.55)$ \\
Dermatoses without a clear diagnosis & $47(4.28)$ \\
Erythematous-Desquamative Lesions & $40(3.64)$ \\
Dyschromias & $31(2.82)$ \\
Folliculosis & $28(2.55)$ \\
Drug Eruptions & $19(1.73)$ \\
Hair Disorders & $14(1.27)$ \\
Keratinization Disorders & $10(0.91)$ \\
Others & $30(2.73)$ \\
Total & $1098(100.00)$ \\
\hline
\end{tabular}

were evaluated in the group of vascular disorders.

Among the 222 tumors, the ones considered benign were nevi, cysts and tumors such as seborrheic keratosis, dermatofibromas, dermatosis papulosis nigra, acrochordons and syringomas, which accounted for 188 (85\%) of the total. The most common malignant tumors upon clinical examination were basal cell carcinoma (BCC), squamous cell carcinoma (SCC) and malignant melanoma (MM). Actinic keratosis and cutaneous horn were classified as pre-malignant tumors.

Seborrheic dermatitis was the most frequent erythematous-desquamative disease (35 cases; 88\%), followed by psoriasis ( 4 cases; $10 \%$ ).

Among skin infections, suspected dermatophytosis lesions were the most common, followed by viral, bacterial and fungal dermatoses, and a case of mucocutaneous leishmaniasis properly diagnosed.

Allergies were responsible for 83 cases, with nonsteroidal anti-inflammatory drugs (NSAIDs)/analgesics being the most frequently prescribed drugs.

Fourteen (4\%) patients were hospitalized due to dermatological conditions (Table 2). Only 16 (4\%) of the 359 patients that were evaluated did not present any skin lesions.

The dermatology ward arose under adverse conditions through the hands of Dr. Charles James White $(1868$ - 1964) and Dr. John Templeton Bowen (1857 - 1940), in 1900 in Massachusetts, with a growing number of cases of syphilis. The average length of hospitalization in the early twentieth century for skin diseases was 32 days. With the introduction of the arsenic treatment by the German researcher Paul Ehrlich (1854-1915), a "syphilology" sector was created in hospitals between 1913-1929, where these sectors were later consolidated into dermatology departments. ${ }^{4}$

TABLE 2: Descriptive analysis of dermatological causes of hospitalization at Mario Covas State Hospital, Santo Andre - Sao Paulo, 2009

\begin{tabular}{ll}
\hline Dermatological Causes of Hospitalization & N (\%) \\
\hline Erythroderma & $4(28.57)$ \\
Drug Eruptions & $2(14.28)$ \\
Collagenosis & $2(14.28)$ \\
Bacterial Infection & $2(14.28)$ \\
Viral Infection & $1(7.14)$ \\
Fungal infection & $1(7.14)$ \\
Mucocutaneous leishmaniasis & $1(7.14)$ \\
Dermatoses without a clear diagnosis & $1(7,14)$ \\
Total & $14(100.00)$ \\
\hline
\end{tabular}


In this study the four most prevalent groups of dermatological diseases were photodermatoses, neoplasms, onychopathies, and vasculopathies. Among infectious diseases, dermatophytosis was the most frequent, suggesting that fungi caused most onychopathies. This is consistent with the epidemiological and attitudinal profiling conducted in Brazil, which revealed that superficial mycoses, pigmentation disorders, allergies, dermatitis, and acne are among the most prevalent diseases. ${ }^{5}$ The limitation of this study is that it was solely based on clinical dermatologic examinations and photographs, with no additional examination.

We observed serious cases of pharmacodermias such as SJS and TEN, which required extreme care in single rooms. Patients with good general condition presenting with erythema multiforme, fixed pigmented erythema, and lichenoid drug eruption shared the room with other patients.

With hospital admissions for skin disorders on the rise, dermatology residency programs should include and/or improve medical interconsultation supervision in hospitals. ${ }^{2}$
In July 2009, Fox et al. proposed "The Society of Dermatology Hospitalists" for dermatologists interested in the intrahospital management of skin diseases. This society aims to develop and improve care and protocols for patients hospitalized with skin disorders, agreeing with Watcher and Goldman (1996) who reported on "hospitalist" doctors, specializing in intrahospital medicine, a new model of medical care - generalist and specialist. ${ }^{6,7}$ In 2006, Watcher highlighted the benefit of this concept to medical education in teaching hospitals and the increase in interdisciplinary medical specialties. ${ }^{8}$ This model has gained ground over the last decade by reducing the costs of healthcare and increasing the quality and satisfaction of patient care. ${ }^{8}$

The prevalence of skin complications and diseases in hospitalized patients justifies a more active and constant presence of dermatologists in hospitals. This physician would be part of a multidisciplinary team providing earlier diagnoses and better quality of life.

\section{REFERENCES}

1. Charman $\mathrm{C}$, Williams $\mathrm{H}$, Kinnear W. Recognition of dermatological conditions by junior doctors on general medical wards. J R Coll Physicians Lond. 1998;32:146-8.

2. Helms AE, Helms SE, Brodell RT. Hospital consultations: Time to address an unmet need? J Am Acad Dermatol. 2009;60:308-11.

3. Sampaio SA, Rivitti EA. Fotodermatoses. In: Dermatologia. São Paulo: Artes Médicas; 2008. p.843-56.

4. Albert MR, Mackool BT. A Dermatology ward at the beginning of the 20th century. J Am Acad Dermatol. 2000;42:113-23.

5. Lupi 0, Nunes S, Gomes Neto A, Pericles C. Doenças dermatológicas no Brasil: perfil atitudinal e epidemiológico. An Bras Dermatol. 2010;85(1 Supl 1):S5-19.

6. Fox LP, Cotliar J, Hughey L, Kroshinsky D, Shinkai K. Hospitalist dermatology. J Am Acad Dermatol. 2009;61:153-4.

7. Watcher RM, Goldman L. The emerging role of "hospitalists" in the American health care system. N Engl J Med. 1996;335:514-7.

8. Watcher RM. Reflections: The Hospitalist Movement a Decade Later. J Hosp Med. 2006;1:248-52.

\author{
MAILING ADDRESS: \\ Luciana Cirillo Maluf Azevedo \\ Rua Marcos Mélega, 150 - D1. - Alto de Pinheiros \\ 05466-010 São Paulo, SP \\ E-mail:lcmaluf@botmail.com
}

How to cite this article: Azevedo LCM, Machado Filho CDS, Andrade MSJ, Nahas AB, Faccin MP. The importance of the dermatologist at the hospital. An Bras Dermatol. 2012;87(3):501-3. 